\author{
Katarzyna Pietras \\ University of Warsaw \\ Faculty of Geography and Regional Studiem \\ Department of Climatology \\ e-mail: migi4@op.pl
}

\title{
COMPARISON OF AIR TEMPERATURE CHARACTERISTICS IN FOREST COMMUNITIES IN PUSZCZA BORECKA AND IN OPEN SPACE
}

\begin{abstract}
Changes in similarities of five forest communities and of open space taking place during the year were analyzed in the scope of twelve daily and monthly characteristics of air temperature. The density of tree crowns having impact on the level of solar radiation reaching the ground during the day and the level of long term nocturnal emissions is the most important factor shaping thermal conditions in the forest.
\end{abstract}

Key words: air temperature, similarities of thermal conditions, forest communities, Puszcza Borecka (Borecka Primeval Forest), J.H. Ward clustering method.

Puszcza Borecka (Borecka Primeval Forest) is located to the north-east of Giżycko in the western part of Pojezierze Ełckie (Ełk Lake District). It is a forest community with an area of almost $200 \mathrm{~km}^{2}$, distinguishing itself by the tree stand structure, large diversity of forest communities and a small degree of transformation by man which manifests itself by the concordance of habitats and plants overgrowing them (Polakowski 1961, Kondracki 1972). A series of field measurements ${ }^{1}$ were carried out in Puszcza Borecka between March 1, 2007 and February 29, 2008. A measurement network was created which was to take into consideration the mosaic structure of the sub-canopy climate, stemming from the diversified tree stand structure (Bednarek et al., 1979). Six measuring stations were located in the research area, in which at the level of $0.25,2.0$ and 5.0 meters above the ground, under anti-radiation protection, electronic data loggers EBI-20-TH were placed. Every ten minutes, these loggers measured and registered the relative air temperature and humidity.

\footnotetext{
${ }^{1}$ Scientific work financed, by Ministry of Science and Higher Education.
} 
Five research stations were distributed in the western part of Puszcza Borecka (in the Diabla Góra and Lipowa Góra Forestries), in forest communities diversified in regard to species, tree crown density, undergrowth and underwood thickness, degree of foliage depending on the phenologicalecological season and moisture of the undergrowth. They included fresh mixed forest, dry-ground forest, alder carr, marshy coniferous forest and young spruce-tree forest. The sixth measuring station was located about 1,5 kilometers to the west of the forest border. Data collected there constituted the background for all climate analysis inside the forest.

Using data clustering, were analyzed the similarities between the examined forest communities and open spaces in regard to temperature characteristics (monthly average, the highest and lowest mean daily values, the highest and lowest mean monthly values, the highest and lowest daily maximum and minimum as well as the mean monthly amplitude and the mean daily amplitude in following months). The J.H. Ward hierarchical clustering method was used. It uses an analysis of variance approach to evaluate the distances between clusters. This method attempts to minimize the sum of squares so that any two clusters be as small as possible. Euclidean distance in multidimensional space was used as a similarity function (Parysek 1982, Kicińska 2001).

This method, due to value standardization, lets compare objects characterized by different data with various orders of magnitude and variable units. Dendrograms, i.e. fusions made at each successive stage of analysis (Fig. 1-12) are the graphic end effect of the analysis.

Similarities of the examined characteristics of air temperature during successive months of the examined period are as follows.

In March, marshy coniferous forest and dry-ground forest were the most similar in regard to thermal characteristics. Open space was characterized by a small divergence in air temperature as compared to the two aforementioned forest communities. Mixed forest, alder carr and spruce-tree forest constituted the second point group with a similar air temperature. However, the degree of similarity in these communities was smaller.

In April, as it was in March, it was possible to divide all the measuring stations into two groups with similar thermal characteristics. The similarity between marshy coniferous forest and dry-ground forest, i.e. communities which in the Spring had a small tree crown content, and open space was the same as in March. The similarity between mixed forest and alder carr increased while the similarity between these two forest communities and spruce-tree forest decreased, as compared to March.

In May, two forest community pairs with similar characteristics of air temperature came into being. They were marshy coniferous forest and dry-ground forest and mixed forest and alder carr. Between surfaces belonging to one pair the similarity value was 1 . Also among the aforementioned two pairs of forest communities differences in characteristics of air temperature were relatively small. The spruce tree forest, however, distinguished itself by large thermal distinctiveness. The crown of its trees had the greatest density and the 
trunk layer was very densely filled with branches. In May, the open air station distinguished itself by contrasting air temperature conditions in relationship to stations located within Puszcza Borecka.

In June, air temperature in the mixed forest, dry-ground forest, marshy coniferous forest, and alder carr had the same characteristics because, at that time, foliage in these forest communities was fully developed. Large differences in regard to other forest measuring stations took place in the spruce-tree forest in which vegetation was of the greatest density. Thermal characteristics of the station located in open space demonstrated large distinctiveness as compared to research areas located in Puszcza Borecka.

In July, as was in June, open space distinguished itself very much in comparison with forest communities. Within the forest area, however, increased the difference between the spruce tree forest and the remaining forest research areas. Also certain differences in air temperature characteristics began to appeared in the alder carr, as opposed to the marshy coniferous forest, dry-ground forest and mixed forest.

In August, air temperature in the spruce-tree forest had the same characteristics as that in the mixed forest and the dry-ground forest. It was also similar in the marshy coniferous forest and in alder carr. This led to the division of the entire forest area into two groups, of large similarity, due to the fact that in this month, vegetation in Puszcza Borecka was fully developed. Open space, however, showed very large dissimilarity of thermal conditions as compared to all the stations located under tree crowns.

In September, diminished the similarity of air temperature characteristics between the mixed forest and the spruce tree forest and the dry ground forest as well as between the marshy coniferous forest and alder carr. However, the similarity between the marshy coniferous forest and the dry ground forest increased because of the beginning of the leaf shedding process which caused a decrease in the content of tree crown canopies in the dry ground forest. Two forest community groups came into being, both characterized by similar thermal conditions: the mixed forest and spruce tree forest (greater content of tree crowns) as well as the marshy coniferous forest and the dry ground forest (smaller content of tree crowns) and, to a lesser degree, of alder cars. Nevertheless, air temperature in all the forest measuring stations still had similar characteristics. In September, occurred the greatest difference between Puszcza Borecka and the surrounding area.

In October, differences in air temperature between particular forest communities significantly increased. Only the mixed forest and the marshy coniferous forest were characterized by a strong similarity. There was a very large discrepancy between the mixed forest, the marshy coniferous forest and spruce tree forest (treated altogether) and dry ground forest and alder carr, i.e. between communities with large participation of coniferous trees and communities with large participation of deciduous trees. Significantly decreased, however, the difference in air temperature between inner forest space and open space. 
In November, once again, decreased the differences between individual forest communities because the process of leaf shedding ended. The examined characteristics in the marshy coniferous forest, dry grass forest and mixed forest had very similar values. Small differences were observed in the alder carr and much greater in the case of the spruce tree forest which, once again, distinguished itself by the greatest density of tree crowns. In November as well, the open space was characterized by high air temperature, as compared to Puszcza Borecka.

In December, as compared to November, the difference between the mixed forest, dry ground forest, marshy coniferous forest and spruce tree forest diminished. However, the discrepancy in air temperature between the forest measuring stations and area located outside the forest increased.

In January, the characteristics of air temperature in the marshy coniferous forest and dry ground forest were very similar. The air temperature in the mixed forest and spruce tree forest was characterized by a lesser similarity. A large difference was observed between the two aforementioned forest community groups. However, in January, the discrepancy between the forest measuring stations and open space was very small, one of the lowest throughout the year. This gives testimony to the fact that in winter months, the air temperature in the forest and in open space becomes similar.

In February, as in January, there was a large similarity in air temperature between the marshy coniferous forest and dry ground forest. The mixed forest was similar to these two forest communities. Of interest is that, in this month, open space showed quite a large similarity to the aforementioned forest communities in which, in winter, there is a small content of tree crowns.

The greatest difference, however, characterized the station located in the spruce tree forest where vegetation in winter months is characterized by large density.

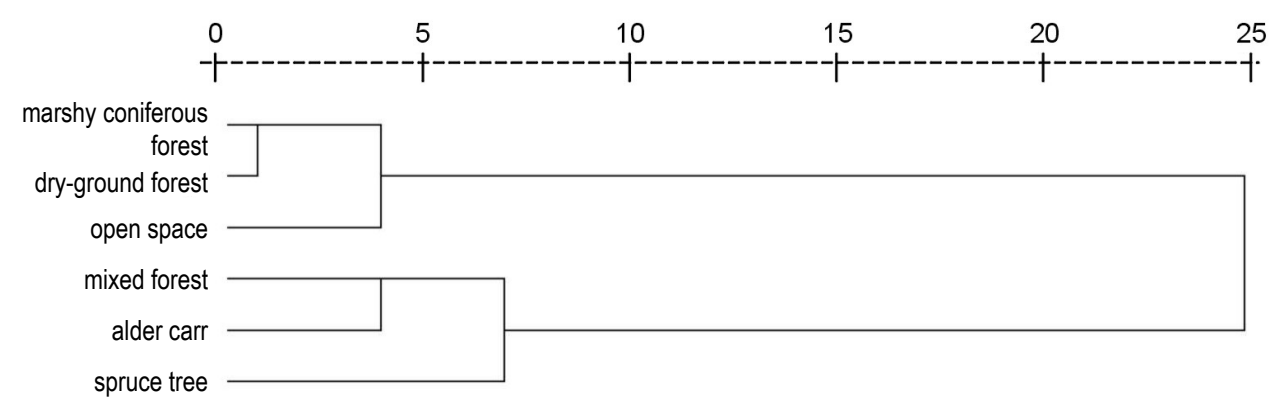

r 1g. 1. Dimilarities in the daily air temperature characteristics in forest communities and in open space - March 


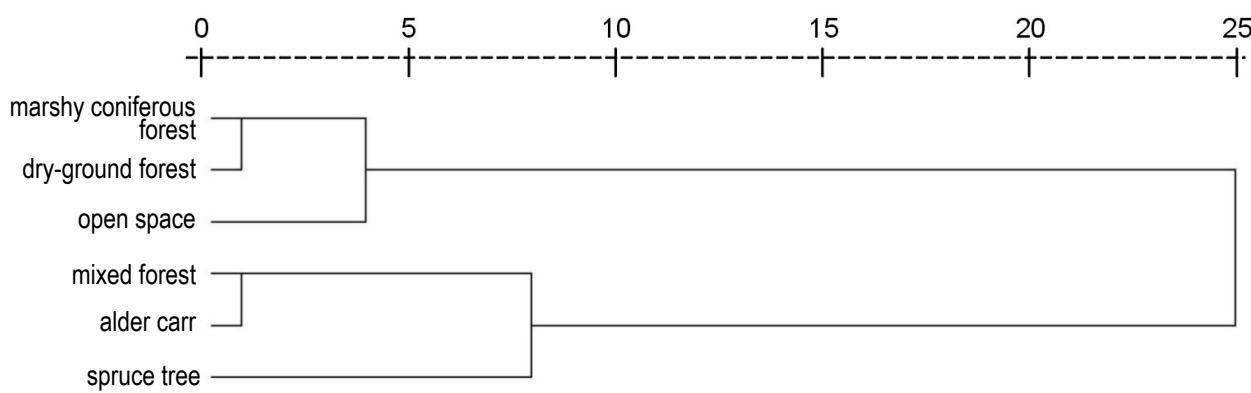

Fig. 2. Similarities in the daily air temperature characteristics in forest communities and in open space - April

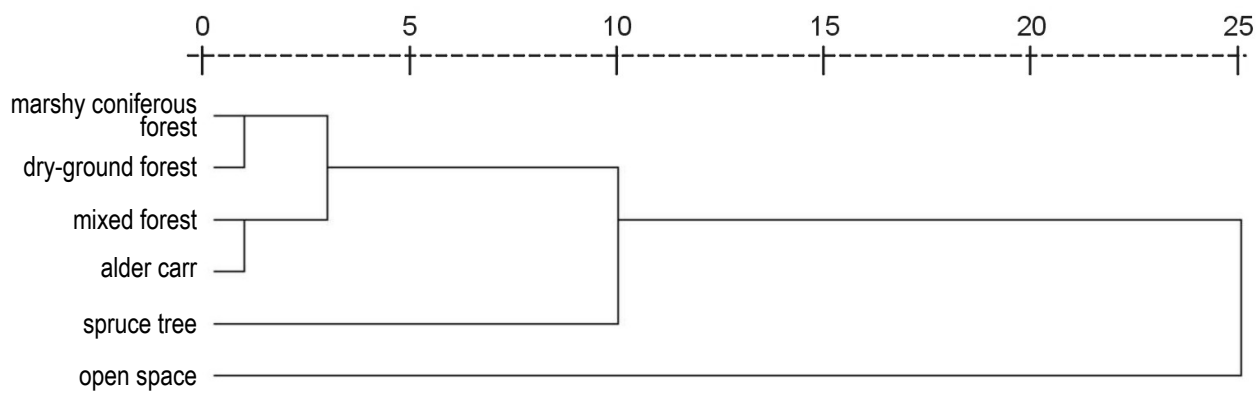

Fig. 3. Similarities in the daily air temperature characteristics in forest communities and in open space - May

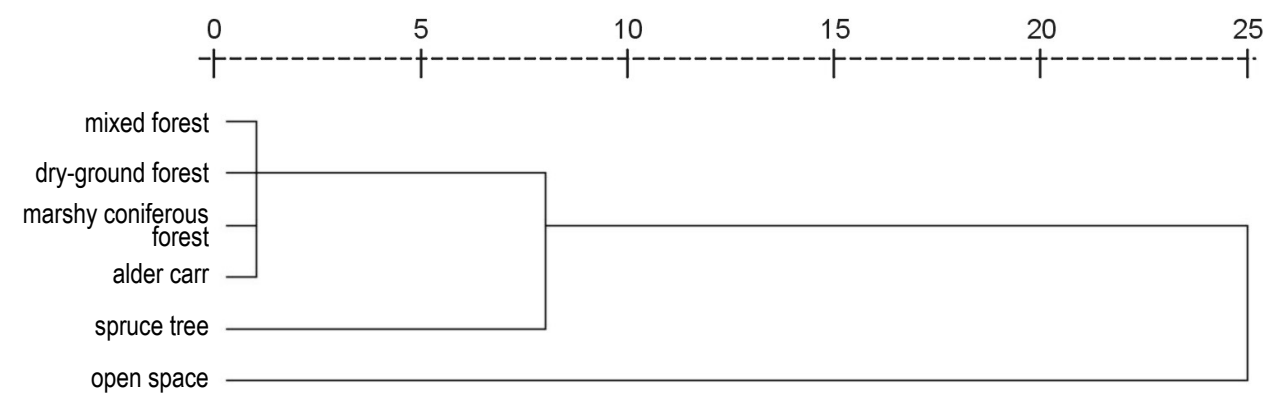

Fig. 4. Similarities in the daily air temperature characteristics in forest communities and in open space - June 


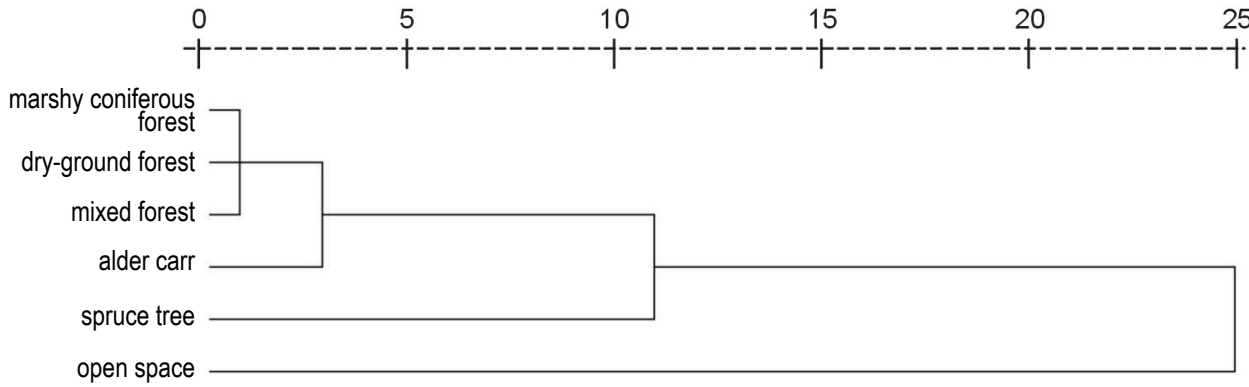

Fig. 5. Similarities in the daily air temperature characteristics in forest communities and in open space - July
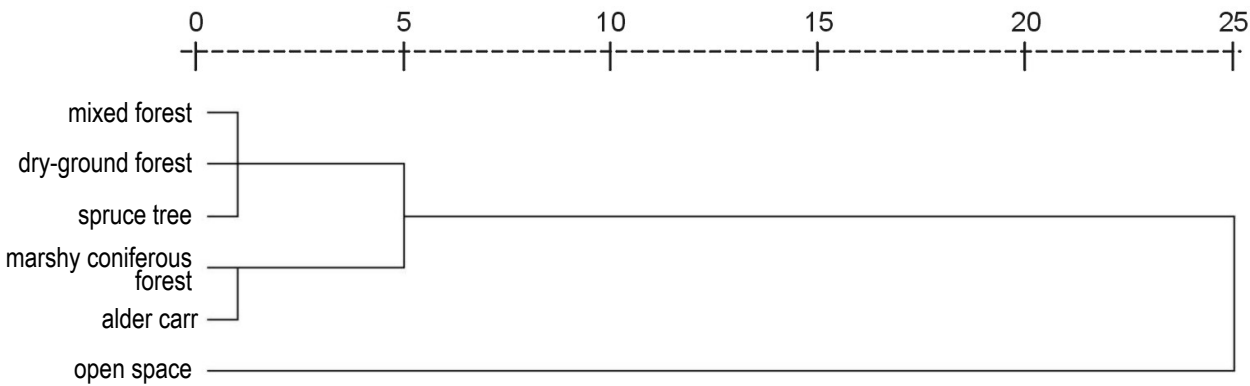

Fig. 6. Similarities in the daily air temperature characteristics in forest communities and in open space - August
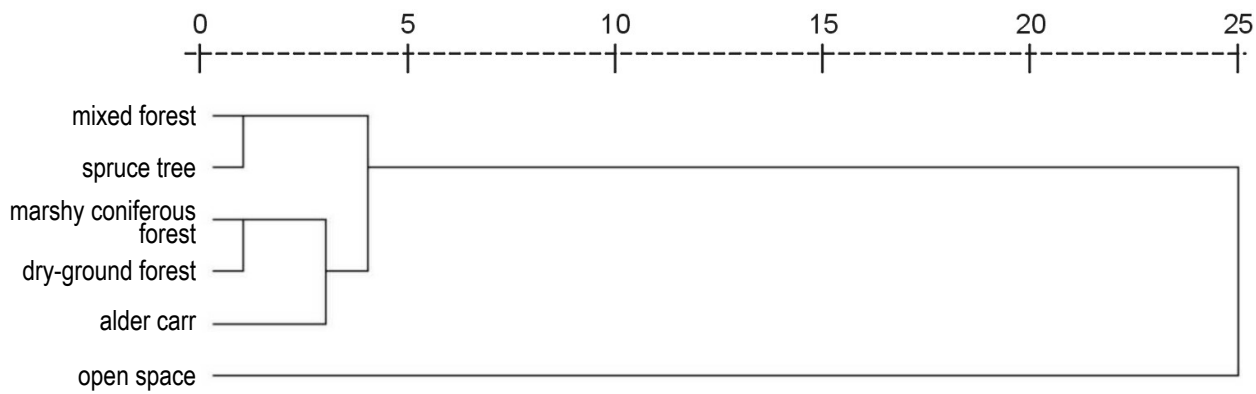

Fig. 7. Similarities in the daily air temperature characteristics in forest communities and in open space - September 

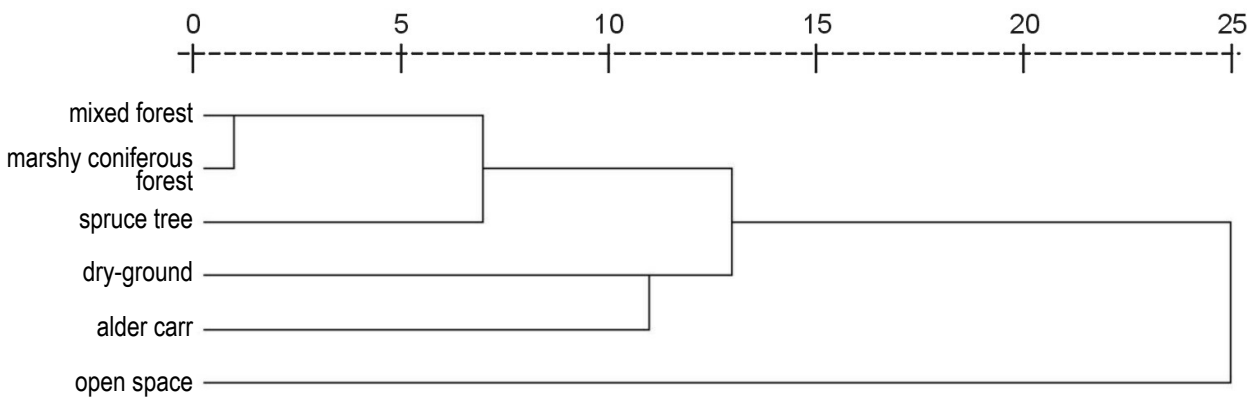

Fig. 8. Similarities in the daily air temperature characteristics in forest communities and in open space - October
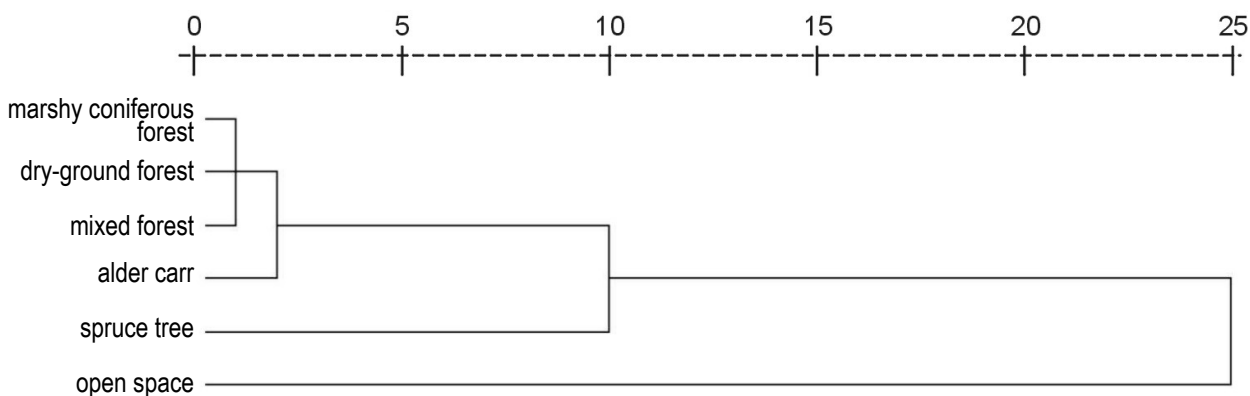

Fig. 9. Similarities in the daily air temperature characteristics in forest communities and in open space -November

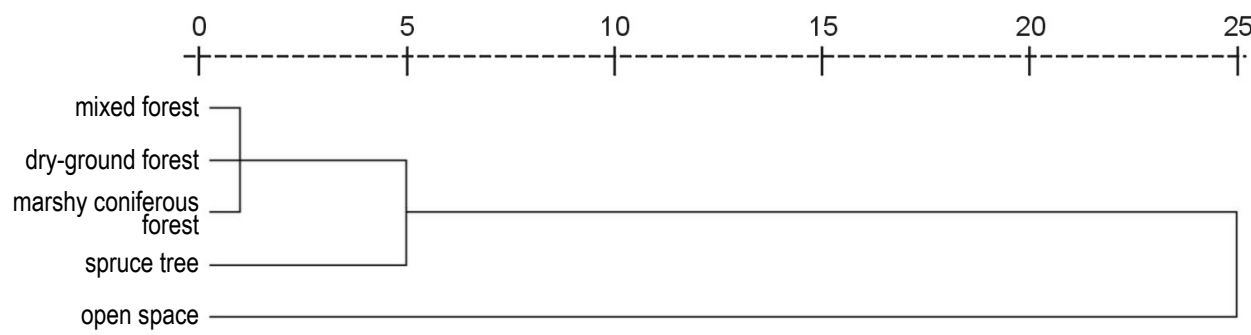

Fig. 10. Similarities in the daily air temperature characteristics in forest communities and in open space - December 


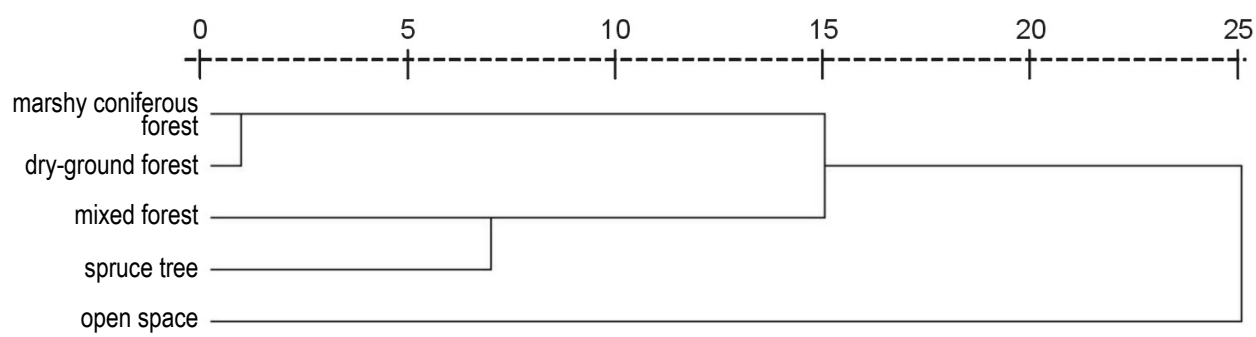

Fig. 11. Similarities in the daily air temperature characteristics in forest communities and in open space - January

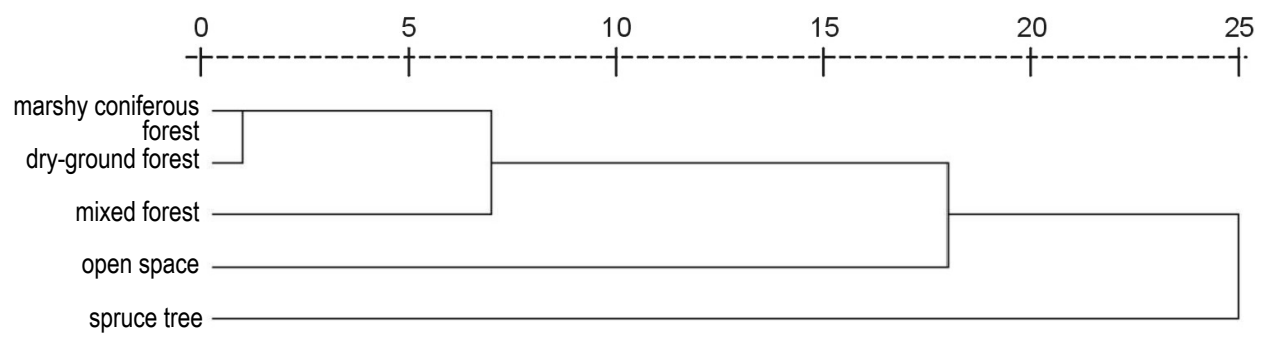

Fig. 12. Similarities in the daily air temperature characteristics in forest communities and in open space - February

The analysis of similarities of thermal conditions during the year in the examined forest communities leads to the following conclusions:

- The fundamental factor of impact on the diversity of thermal conditions in forest communities in Puszcza Borecka (Borecka Primeval Forest) is the tree crown content;

- in the period of full foliage all forest communities have related air temperature characteristics and at that time, open space stands out the most.

- during the seasons of transition diversity of air temperature between forest communities is the greatest;

- outsider the growing season, forest communities with a large share of leaf plants have thermal characteristics similar to that in open space;

- during the entire year, the spruce tree forest is a community with a relatively large thermal diversity which distinguishes itself by a large and constant tree crown content. 


\section{REFERENCES}

Bednarek A., Huculak W., Makowiec M., 1979, Materiaty do ćwiczeń z meteorologii i klimatologii leśnej [Materials for exercises on meteorology and forest climatology], Wydawnictwo SGGW-AR, Warszawa.

Kicińska B., 2001, Wpływ cyrkulacji atmosferycznej na stężenie dwutlenku siarki w powietrzu w Polsce [Impact of atmospheric circulation on sulphur dioxide concentration in the air in Poland], Prace i Studia Geograficzne, 28, Warszawa.

Kondracki J., 1972, Polska pótnocno-wschodnia, [North-eastern Poland] PWN, Warszawa.

Polakowski B., 1961, Stosunki florystyczno-fitosocjologiczne Puszczy Boreckiej ze szczególnym uwzględnieniem lasów leśnictwa Lipowo $i$ Walisko [Floristic-fitosociological relations of Puszcza Borecka with special focus on forests in the Lipowo and Walisko Forestries], PWN, Warszawa.

Parysek J.J., 1982, Modele klasyfikacji w geografii [Classification models in geography], Geografia, 31, Wydawnictwo Naukowe Uniwersytetu im. Adama Mickiewicza w Poznaniu, Poznań. 